\title{
QUALITY OF SLAB TRACK CONSTRUCTION - TRACK ALIGNMENT DESIGN AND TRACK GEOMETRY
}

\author{
Janka ŠESTÁKOVÁ ${ }^{1 *}$ \\ ${ }^{1}$ Department of Railway Engineering, Faculty of Civil Engineering, University of Žilina, Univerzitná \\ 8215/1, 01026 Žilina. \\ "corresponding author: janka.sestakova@fstav.uniza.sk, +421-4-1513 5807.
}

\begin{abstract}
The slab track superstructure design (without ballast) is a perspective construction especially for building tunnels and bridges in the modernized sections of railway tracks in Slovakia. Monitoring of the structure described in this article is focused on the transition areas between standard structure with ballast and slab track construction.
\end{abstract}

\author{
Keywords: \\ Railways; \\ Diagnostics; \\ Slab Track; \\ Track Alignment Design; \\ Track Geometry.
}

\section{Introduction}

Railway superstructure consists of roadway with carrying and guiding function for the driving of railway vehicles. It also transmits traction and braking forces of traction vehicles. Formation of structural elements of the superstructure depends on the required load-carrying capacity of the structure and track capacity. The design should be composed of a small number of structural components, which can be easily assembled to each other, but also disassembled or, by construction technology, assembled in a preassembled component ready to installation. The standard structure of railway superstructure is made up of rails, supporting points (e.g. sleepers), fastening of the rails and ballast bed. The construction of the superstructure, where function of ballast is replaced by improved materials built-in concrete or asphalt foundation layer is called the slab track.

The sufficient quality of roadway requires fulfillment of prescribed conditions in process of building the construction of the superstructure and the substructure. The superstructure of slab track shall be constructed on a structure whose settlement is minimal (the optimum is none). This requirement is achievable by using materials of adequate quality and by accepting methods of prescribed procedures of constructing all layers of the structure. Slab track construction is also affected by the location where is built. The size of the final structure deformation affects the roadway on bridges and in tunnels. Because of final deformation of structure, constructing multi-layers structures with increasing static stiffness (bottom up) for construction of a slab track on the earthworks is needed. Slab track structure consists of (top-down):

- track superstructure:

- rails,

- fastening of the rails to the rail support,

- rail support (sleepers, single supporting points, pre-fabricated or monolithic slab),

- concrete foundation layer (CFL) or asphalt foundation layer (AFL),

- hydraulically bonded foundation layer (HBL),

- track substructure (if slab track construction is built on earthworks):

- frost protective layer (FPL),

- subsoil layers (consolidated or improved material of earthworks in the embankment or earthen cut),

- consolidated soil or bedrock.

Many different types of slab track have been developed and operated on many railway tracks in various modifications of designs. Designs of slab track can be divided into six main categories:

- designs on supporting points with sleeper inserted in concrete slab,

- designs on supporting points with sleeper laid-on concrete slab,

- pre-fabricated designs on supporting points without sleepers,

- monolithic designs on supporting points without sleepers,

- continuous support designs with embedded rail, 
- continuous support designs with clamped rail.[5]

Slab track constructions are on the railway network of the Slovak Republic currently designed and built on the modernized sections of railway lines - mostly in tunnels and on bridges. Monitoring of the track alignment design and track geometry and of the slab track construction in the tunnel is carried out by long-term scientific-research by the Department of Railway Engineering and Track Management in cooperation with the Department of Geodesy of the Faculty of Civil Engineering of the University of Žilina.

Monitoring of experimental section is performed within a comprehensive continuous diagnostics. Verification of results is also performed by discrete diagnostics. Currently, the results of measurement before putting sections into operation and first to fourth operational measurements of track alignment design and track geometry are available.

\section{Description of the experimental sections}

Experimental sections are situated on modernized double-track railway Nové Mesto nad Váhom - Púchov and are located in areas of southern and northern portal of the tunnel Turecký vrch. The track speed in both of tracks is $160 \mathrm{~km} \cdot \mathrm{h}^{-1}$, which ranks the railway line to the category of velocity zone No. 4 (RP4). Superstructure of each section is constructed as a construction with ballast bed and a slab track RHEDA $2000^{\circledR}$ (in tunnel, on bridges and on earthwork). The construction of the superstructure in each section and track in the transition areas is constructed as improved ballast placed in concrete trough. Structural parameters of the experimental sections are described by detail in [2].

Monitoring of track alignment design and track geometry is aimed to determine state of parts of the track structure and the track at all. This kind of monitoring is one of the basic diagnostics activities, in which there is also monitored traffic load, climatic load and the effect of maintenance on track skeleton.

The experimental track sections are marked as:

- section 1.1 (track No. 1, south portal of the tunnel Tureckývrch) and 2.1 (track No. 2, south portal; both sectors of length $175 \mathrm{~m}$; km $102.360000-\mathrm{km} 102.535000$ ):

- $\mathrm{km} 102.360000-\mathrm{km} 102.460500$ construction with ballast bed,

- $\mathrm{km} 102.460500-\mathrm{km} 102.480500$ construction with ballast bed in the concrete trough,

- $\mathrm{km} 102.480500$ - km 102.535000 slab track.

- section 1.2 (track No. 1, north portal of the tunnel Tureckývrch) and 2.2 (track No. 2, north portal); both sectors of length $640 \mathrm{~m}$; $\mathrm{km} 104.200000-\mathrm{km} 104.840$ 000):

- $\mathrm{km} 104.200000-\mathrm{km} 104.720500$ slab track,

- $\mathrm{km} 104.720500-\mathrm{km} 102.480500$ construction with ballast bed in the concrete trough,

- $\mathrm{km} 104.740500$ - km 104.840000 construction with ballast bed.

\section{Diagnostics of the experimental section - diagnostics methods and equipment}

Monitoring of track alignment design and track geometry on experimental section is carried out by continuous method and also by discrete method. So far, five measurements were done:

- a comprehensive diagnostics of track alignment design and track geometry realized by continuously measuring device (measuring trolley $\mathrm{KRAB}^{\mathrm{TM}}$ - Light):

- each section No. 1.1 and No. 2.1 is represented by 701 samples for a comprehensive diagnostics,

- each section No. 1.2 and No. 2.2 is represented by 2,561 samples for a comprehensive diagnostics;

a partial diagnostics of track alignment design and track geometry realized by gauge-checker ROBEL and gauge-checker GEISMAR:

- each section No. 1.1 and No. 2.1 is represented by 288 fixation points for a comprehensive diagnostics,

- each section No. 1.2 and No. 2.2 is represented by 1,009 fixation points for a comprehensive diagnostics,

Discrete method is used to control tolerances of gauge RK and cant PK and monitoring is performed at each fastening point of the rail support. 
Comprehensive diagnostics of track alignment design and track geometry is realized by continuously measuring trolley $\mathrm{KRAB}^{\mathrm{TM}}$ - Light. The measurement is referred to as continuous, but in fact, the data is recorded with the measuring step of $250 \mathrm{~mm}$ :

- gauge tolerance RK (after calculating is also recorded change of gauge ZR),

- alignment of right rail string SP (after calculating is also recorded alignment of left rail string $\mathrm{SL})$,

- rail top level of right rail string VP (after calculating is also recorded rail top level of left rail string VL),

- cant PK,

- quasi-twist on a short base (calculating to a quasi-twist on a base of $1.8 \mathrm{~m}$ long $-\mathrm{ZK}_{1,8}$, on a base of $6.0 \mathrm{~m}$ long $-\mathrm{ZK}_{6,0}$ and on a base of $12.0 \mathrm{~m}$ long $\left.-\mathrm{ZK}_{12,0}\right)$,

- track distance.

\section{Assessment of results of track alignment design and track geometry diagnostics}

Monitoring method used by measuring device $\mathrm{KRAB}^{\mathrm{TM}}$-Light is contact: monitoring of parameters is performed by contact of the sensing device with the element on the track skeleton. The measured data are sent to the NOMAD on-board computer by the KRAB8VNET software and for evaluation are processed in KRAB8.1 software. Generated outputs are based on limits (tolerances, Table 1) which are defined [6]:

- graphs of measured parameters of track alignment design and track geometry,

- tables of local errors - list of exceeded tolerances,

- tables of section evaluation, which is based on standard tolerances and quality numbers[9].

Results of quality section evaluation according to valid technical standards and regulations:

- Geometrical Position and Arrangement of 1435 mm Gauge Railways, SÚTN Bratislava, 1999 and Amendment 1, SÚTN Bratislava, 2002 for railway tracks of track speeds of $120 \mathrm{~km} \cdot \mathrm{h}^{1}<\mathrm{V} \leq 160 \mathrm{~km} \cdot \mathrm{h}^{-1}$ (RP4),

- comprehensive continuous monitoring,

- partial-discrete monitoring,

- ZSR SR 103-7 (S) Measurement and Evaluation of Track Geometry by Measuring Trolley KRAB (in Slovak), GR ZSR, 2008.

Diagnostics of structure layout and track geometry of the track section:

- measurement before putting sections into operation (MSO) were made in period 10.07. 11.7.2012, 2.10. - 3.10.2012,

- first operational measurement (PO1) 09.04. - 10.04.2013, 21.04-22.04.2013,

- second operational measurement (PO2) 08.10. - 09.10.2013, 21.10. - 22.10.2013,

- $\quad$ third operational measurement (PO3) 25.5.2014 and 28.5.2014,

- fourth operational measurement (PO4) 29.10.2014 [8].

Measured parameters were evaluated according to maximal input tolerances for acceptance of works with use of new material (MSO) and according to operational tolerances and maximal operational tolerances (PO1, PO2, $\mathrm{PO}$ and PO4) (Table 1).

Evaluation of parameters of track alignment design and track geometry is provided in sectional evaluation of the track (length of evaluated sections is max. 1,000 m) by statistical processing of standard tolerances, calculated from tolerances from the median line, which is calculated from the dynamic component of track geometry parameters (SK, RK, PK, VK) at wavelengths of $1 \mathrm{~m}$ to $25 \mathrm{~m}$ measured every $250 \mathrm{~mm}$. Standard tolerances (SDO) expresses irregular course of track geometry parameters of evaluated section.

The overall super evaluation of test sections (so called "section evaluation") is given by:

- the quality number of the section (SQN) of each measured parameter (SK, RK, PK, VK),

- the quality mark (QM), as an assessment of both track alignment design and track geometry quality in evaluated section,

- the tamping mark (TM), which is used to decide, whether or not to use a tamping machine and varies from SQN by excluding the gauge tolerances, which tamping machine does not maintain,

- the quality number (QN). 
Table 1: The tolerances of the relative geometric parameters of the track for RP4 [6].

\begin{tabular}{|c|c|c|c|c|c|c|c|}
\hline \multirow{2}{*}{$\begin{array}{l}\begin{array}{c}\text { Measured } \\
\text { parameter }\end{array} \\
R K(\mathrm{~mm}) \\
\end{array}$} & \multicolumn{2}{|c|}{$\begin{array}{l}\text { Maximal input } \\
\text { tolerances }\end{array}$} & \multicolumn{2}{|c|}{$\begin{array}{l}\text { Operational } \\
\text { tolerances }\end{array}$} & \multicolumn{2}{|c|}{$\begin{array}{c}\text { Maximal } \\
\text { operational } \\
\text { tolerances }\end{array}$} & \multirow{2}{*}{$\begin{array}{c}\text { Note } \\
-\end{array}$} \\
\hline & -2 & 2 & -3 & 5 & -5 & 10 & \\
\hline$Z R\left(\mathrm{~mm} \cdot \mathrm{m}^{-1}\right)$ & \multicolumn{2}{|c|}{2} & \multicolumn{2}{|c|}{3} & \multicolumn{2}{|c|}{4} & - \\
\hline$P K(\mathrm{~mm})$ & -3 & 3 & -6 & 6 & -8 & 8 & - \\
\hline $\begin{array}{l}\text { Measured } \\
\text { parameter }\end{array}$ & \multicolumn{2}{|c|}{ Maximal value } & \multicolumn{2}{|c|}{$\begin{array}{c}\text { Operational } \\
\text { value }\end{array}$} & \multicolumn{2}{|c|}{$\begin{array}{c}\text { Maximal } \\
\text { operational value }\end{array}$} & Note \\
\hline \multirow{3}{*}{$\begin{array}{l}Z K(1: n) \\
(\mathrm{mm} / \text { base })\end{array}$} & \multicolumn{2}{|c|}{$\begin{array}{c}1: 250 \\
(7.2 ; 4.0)\end{array}$} & \multicolumn{2}{|c|}{$\begin{array}{c}1: 250 \\
(7.2 ; 4.0)\end{array}$} & \multicolumn{2}{|c|}{$\begin{array}{c}1: 167 \\
(10.8 ; 5.99)\end{array}$} & $\begin{array}{c}\text { on measuring base } \\
1.8 \mathrm{~m}\end{array}$ \\
\hline & \multicolumn{2}{|c|}{$\begin{array}{c}1: 832 \\
(7.2 ; 1.20)\end{array}$} & \multicolumn{2}{|c|}{ not evaluated } & \multicolumn{2}{|c|}{$\begin{array}{c}1: 250 \\
(24.0 ; 4.0)\end{array}$} & $\begin{array}{c}\text { on measuring base } \\
6.0 \mathrm{~m}\end{array}$ \\
\hline & \multicolumn{2}{|c|}{ not evaluated } & \multicolumn{2}{|c|}{ not evaluated } & \multicolumn{2}{|c|}{$\begin{array}{c}1: 333 \\
(36.0 ; 3.0)\end{array}$} & $\begin{array}{c}\text { on measuring base } \\
12.0 \mathrm{~m}\end{array}$ \\
\hline $\begin{array}{l}\text { Measured } \\
\text { parameter }\end{array}$ & \multicolumn{2}{|c|}{$\begin{array}{l}\text { Maximal input } \\
\text { relative } \\
\text { tolerances }\end{array}$} & \multicolumn{2}{|c|}{$\begin{array}{l}\text { Relative } \\
\text { operational } \\
\text { tolerances }\end{array}$} & \multicolumn{2}{|c|}{$\begin{array}{c}\text { Maximal } \\
\text { operational } \\
\text { relative } \\
\text { tolerances }\end{array}$} & Note \\
\hline$V L, V P(\mathrm{~mm})$ & -3 & 3 & -6 & 6 & -8 & 8 & - \\
\hline$S L, S P(\mathrm{~mm})$ & -3 & 3 & -6 & 6 & -8 & 8 & - \\
\hline
\end{tabular}

Section evaluation is carried out according to [7]-by:

- the quality number of evaluated section, which is used to assess the quality of track alignment design and track geometry of the track and calculated from the standard tolerances of the measured parameters of evaluated section (SK, RK, PK, VK); to evaluate the quality of track alignment design and track geometry are set recommended standard tolerances values of each parameter and quality number values for RP4 are listed in Table 2,

- the quality marks of each parameters (SK, RK, PK, VK); the results of evaluation by the quality marks are indicative and additional and are not binding for the evaluation of track alignment design and track geometry; assessments that are defined at various intervals of the quality marks are only recommendatory (Table 3 ).

Table 2: Limit values of standard tolerances (SDO) and quality numbers (QN) for RP4[7].

\begin{tabular}{|c|c|c|c|c|c|c|c|}
\hline \multicolumn{3}{|c|}{ Maximal input tolerances } & \multicolumn{3}{c|}{ Maximal operational tolerances } \\
\hline$S D O_{S K}$ & $S D O_{R K}$ & $S D O_{P K}$ & $S D O_{V K}$ & $S D O_{S K}$ & $S D O_{R K}$ & $S D O_{P K}$ & $S D O_{V K}$ \\
\hline 0.7 & 0.8 & 0.7 & 0.8 & 0.9 & 1.0 & 1.1 & 1.5 \\
\hline \multicolumn{3}{|c|}{$Q N$} & \multicolumn{5}{c|}{$Q N$} \\
\hline \multicolumn{3}{|c|}{1.8} & \multicolumn{5}{c|}{2.5} \\
\hline
\end{tabular}

Table 3: The scale of quality marks (QM) according to quality section evaluation [7].

\begin{tabular}{|c|c|c|}
\hline $\begin{array}{c}\text { Interval of } \\
\text { quality marks }\end{array}$ & $\begin{array}{c}\text { Verbal assessment section according to the } \\
\text { quality mark }\end{array}$ & $\begin{array}{c}\text { Color of the quality } \\
\text { mark in printed output }\end{array}$ \\
\hline $0<Q M \leq 2$ & state of track geometry is satisfactory in section \\
evaluated & no color marking \\
\hline $2<Q M \leq 3$ & $\begin{array}{c}\text { it is recommended to design the repair of track } \\
\text { geometry in the section evaluated into maintenance } \\
\text { work plan }\end{array}$ & green color \\
\hline
\end{tabular}




\begin{tabular}{|c|c|c|}
\hline $3<Q M<4$ & $\begin{array}{c}\text { it is recommended to perform the repair of track } \\
\text { geometry in the section evaluated to the nearest } \\
\text { control }\end{array}$ & violet color \\
\hline $4 \leq Q M \leq 6$ & $\begin{array}{c}\text { it is recommended to perform immediate measures in } \\
\text { the section evaluated to ensure the safety of } \\
\text { operation }\end{array}$ & red color \\
\hline
\end{tabular}

\section{Quality of track sections}

Development of track alignment design and track geometry of monitored sections is shown in Tables 4 - 7. Evaluation of tolerances of track alignment design and track geometry in RP4 according to $[6,7]$ joins evaluation of straight track, track in curve or in transition curve. Local errors of the measured parameters are calculated separately for sections with the standard structure of railway superstructure (SSRS), for transition areas (TA) and sections with the slab track structure (ST).

\section{Quality assessment of diagnosed sections}

Monitoring of experimental section is carried out with semi-annual basis since July 2012. Measurements for acceptance of works (MSO) took place about two days before the start of operation. After the measurements, supplier carried out maintenance works of track alignment design and track geometry and microgeometry of rail head repair works in sections with ballast placed in concrete trough (transition area) and standard structure of railway superstructure. Supplier has not provided the data of repair works. The operational measurement has been realized four times (PO1 to $\mathrm{PO} 4)$. In the second operational measurement (PO2), there were first diagnosed local errors of rail top level of right rail string (VP) and rail top level of left rail string $(\mathrm{VL})$ conforming the results of monitoring by track geometry car of infrastructure manager.

Table 4: Quality in section No. 1 in track No. 1.

\begin{tabular}{|c|c|c|c|c|c|c|c|c|c|c|c|c|c|c|c|c|c|}
\hline \multirow[b]{2}{*}{ 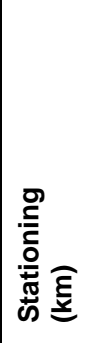 } & \multirow{2}{*}{ 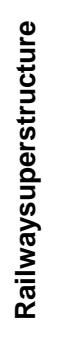 } & \multirow[b]{2}{*}{ 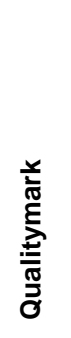 } & \multicolumn{3}{|c|}{ MSO } & \multicolumn{3}{|c|}{ P01 } & \multicolumn{3}{|c|}{ PO2 } & \multicolumn{3}{|c|}{ PO3 } & \multicolumn{3}{|c|}{ PO4 } \\
\hline & & & $\begin{array}{l}\frac{n}{2} \\
\frac{0}{5} \\
\frac{0}{\pi} \\
0 \\
0\end{array}$ & ઠิ & z & 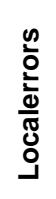 & రิ & శ్ & 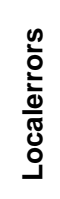 & రิ & త్ర & 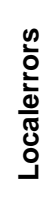 & రิ & త్ర & 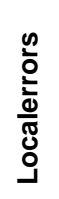 & ઠิ & ટૂ \\
\hline 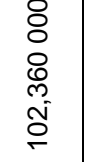 & $\begin{array}{l}\infty \\
\frac{n}{\infty} \\
\infty \\
\infty\end{array}$ & $\sum_{0}^{\frac{x^{\circ}}{0}}$ & 10 & 2.07 & & 0 & 2.67 & & 0 & 2.25 & & 0 & 1.88 & & 0 & 3.12 & \\
\hline 究 & & ta & & & & & & & & & & & & & & & \\
\hline & $\leftleftarrows$ & & 0 & & 1.19 & 0 & & 1.88 & 2 & & 1.89 & 4 & & 1.96 & 4 & & 2.36 \\
\hline 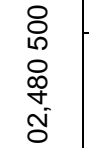 & & $\sum_{0}^{\frac{\alpha}{0}}$ & & 1.88 & & & 2.00 & & & 2.03 & & & 2.03 & & & 2.05 & \\
\hline 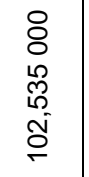 & 5 & $\sum_{0}^{\frac{F}{2}}$ & 0 & 2.50 & & 0 & 3.21 & & 1 & 3.37 & & 0 & 3.49 & & 0 & 3.50 & \\
\hline
\end{tabular}


Table 5: Quality in section No. 2 in track No. 1.

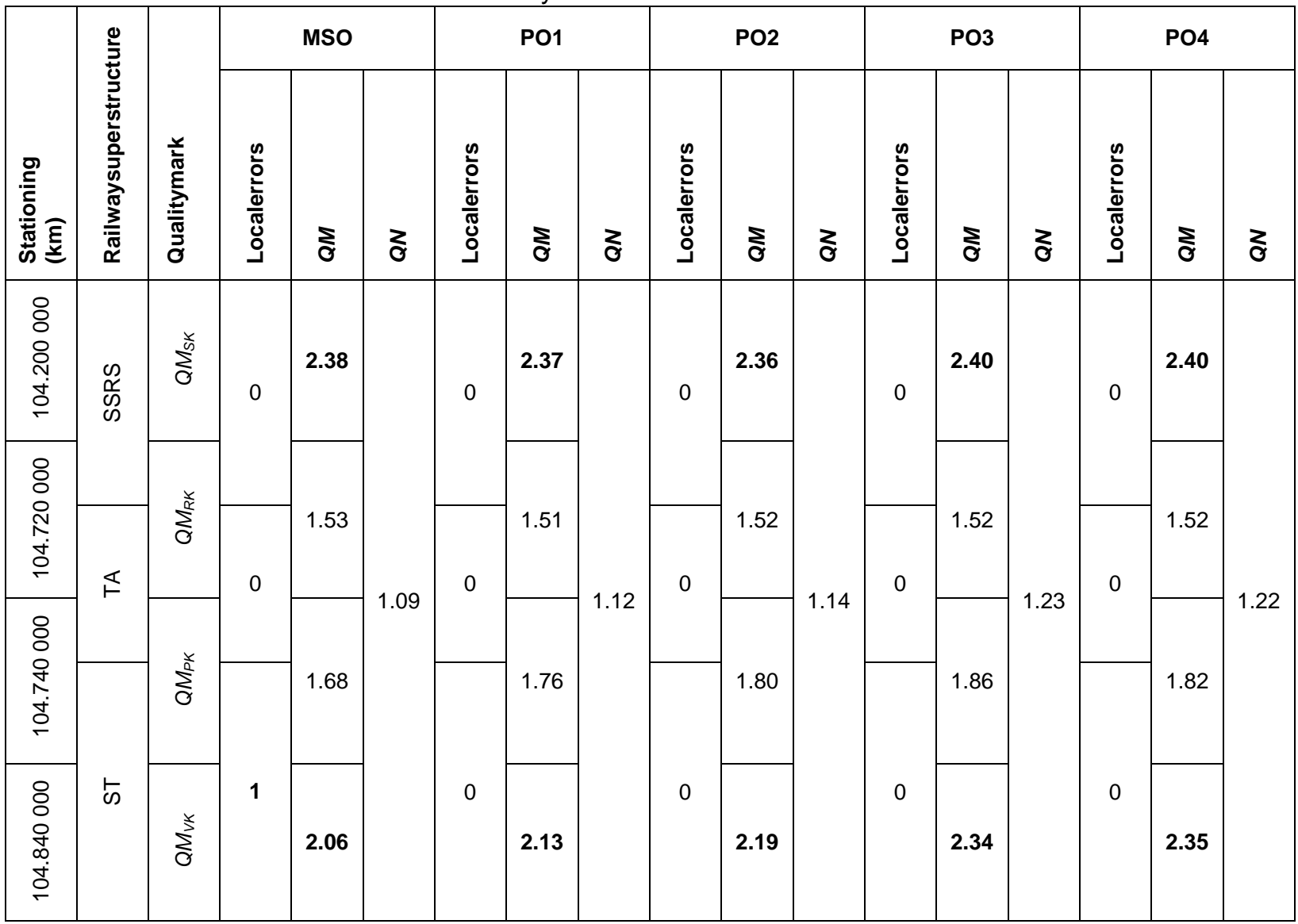

Table 6: Quality of section No.1 in track No.2.

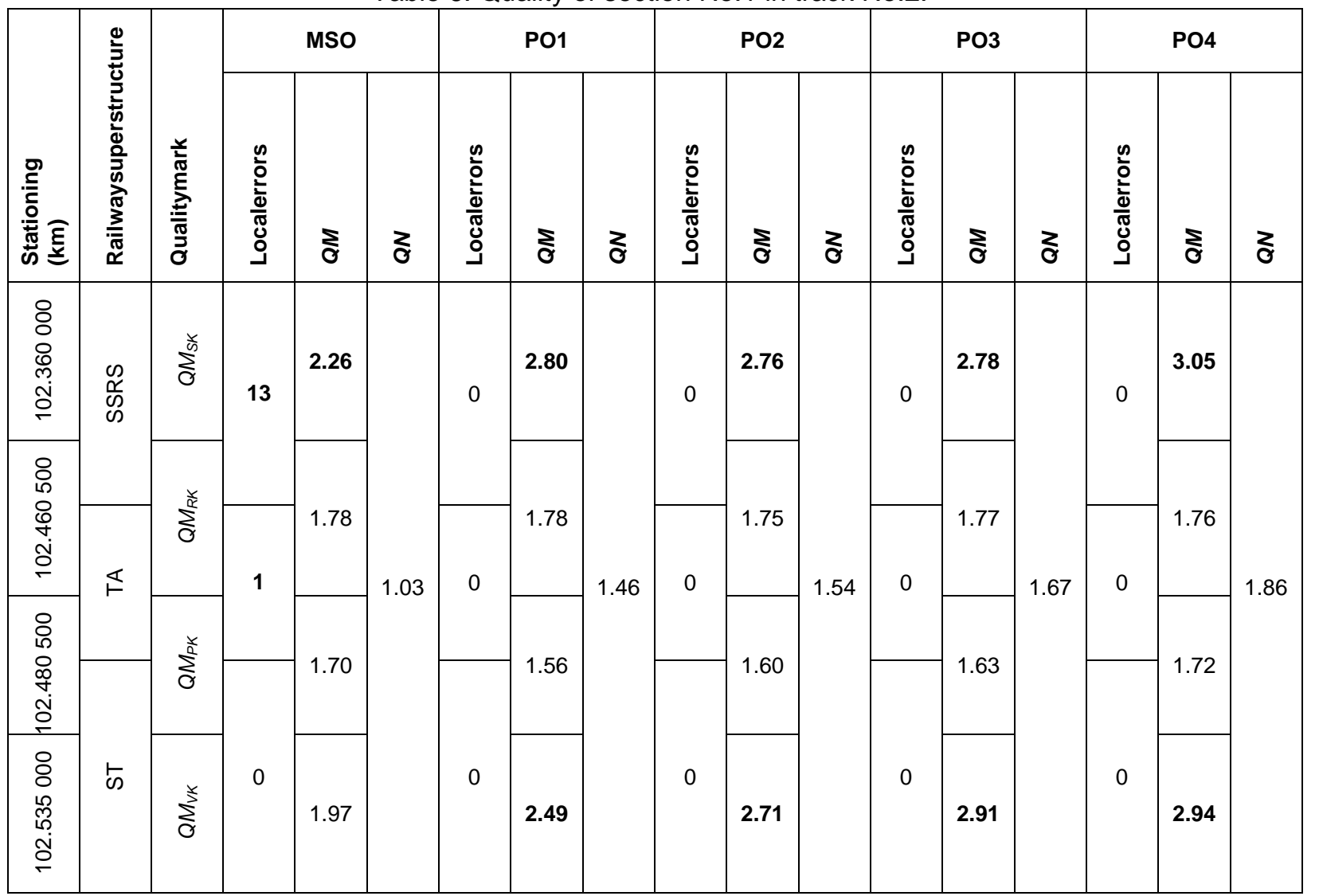


Table 7: Quality of section No. 2 in track No.2.

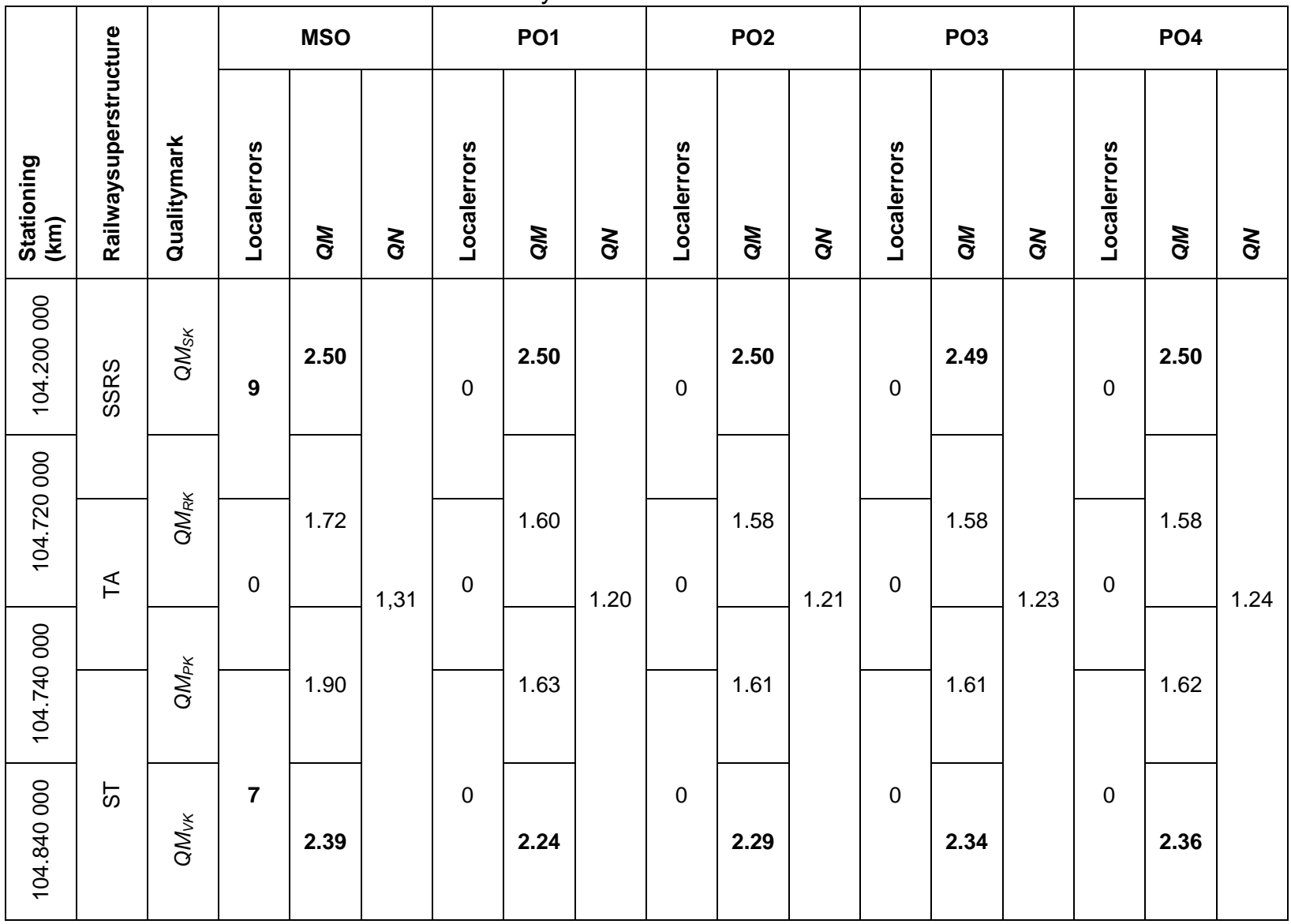

In November 2014, there were made corrective maintenance interventions in transition area to eliminate these errors. Data of interventions (track lifting) will be incorporated into subsequent assessment of operational measurement of the experimental section.

From the overview of quality assessment of diagnosed sections (overview of local errors and section evaluations - the quality marks and the quality numbers) in the Tables $4-7$, it is clear that local errors were eliminated by maintenance interventions carried out after input measurements. During operation, in all sections were evaluated higher values (worse) of quality marks of directional (SK) and vertical (VK) alignment of the track and slightly increasing values of each geometrical parameter (SK, RK, PK, VK). Section with the lowest quality shown by evaluation is section of track No. 1 in the area of southern portal, where incidence of local errors is the highest as well as the quality mark and the number of quality. There is expected improvement of the quality of all sections after maintenance interventions.

\section{Conclusions}

The slab track, as a construction of railway superstructure, is a part of modernized track sections of network of Slovak Railways, which are according to the velocity categorized to the category of RP4 and RP5 velocity zones (speed over $120 \mathrm{~km} \cdot \mathrm{h}^{-1}$ ). Monitoring of track alignment design and track geometry of railway tracks of these categories is obligatory carried out by the manager of infrastructure by methods of comprehensive diagnostics. The monitoring realized by the Department of Railway Engineering and Track Management is only comparative and results of both methods are comparable. The operational monitoring carried out by methods of comprehensive diagnostics is enabled way of track diagnostics. The result of this monitoring is a set of information about quality of construction, from which it is possible to predict further progress of the structure and then plan necessary time and inexpensive maintenance interventions. 


\section{Acknowledgement}

There are partial results of the VEGA 1/0597/14 grant "Analysis of methods used to measure the unconventional railway track construction from the point of view of accuracy and reliability" in the paper.

\section{References}

[1] IŽVOLT, L. - ŠMALO, M.: Historical Development and Applications of Unconventional Structure of Railway Superstructure of the Railway Infrastructure of the Slovak Republic, In: Civil and Environmental Engineering. Scientific - Technical Journal. Volume 10, Issue 2 (2014). EDIS University of Žilina, 2014. ISSN 1336-5835, Žilina.

[2] IŽVOLT, L. - ŠESTÁKOVÁ, J. - ŠMALO, M. - GOCÁLOVÁ, Z.: Monitoring of the Track Geometry Quality around the Portals of New Tunnel Construction Turecky vrch - Preliminary Results, In: Communications: Scientific Letters of the University of Žilina, Vol. 16, no. 4, 2014, . ISSN 13354205.

[3] IŽVOLTOVÁ, J. - VILLIM, A. - PISCA, P.: Analysis of Height Changes of Ballast-Less Track. In: Geodézia, kartografia a geografické informačné systémy, VIII. vedecko-odborná medzinárodná konferencia. Zborník príspevkov. Tatranské Matliare, SR, 17.-19.09.2014. Košice: Technická univerzita, 2014. ISBN 978-80-553-1781-6.

[4] KREJČIŘ́́KOVÁ, H. - IŽVOLT, L. - ŠMALO, M.: Historical Development and Application of Nonconventional Permanent Way Structure on the Railway Infrastructure in Czech and Slovak Republic, In: Nová železniční technika. KPM CONSULT, a. s. Roč. 22, č. 2, 2014. ISSN: 12103942, Brno, Česká republika.

[5] PLÁŠEK, O. - ZVĚŘINA, P. - SVOBODA, R. - MOCKOVČIAK, M.: Railway structures. Track substructure and superstructure, Akademické nakladatelství CERM, s. r. o. Brno, 2014, ISBN 80214-2621-7, Brno, Česká republika.

[6] STN 736360 (1999) Track alignment design and track geometry of normal-gauge tracks (in Slovak), SÚTN Bratislava a Zmena 1 (2002), SÚTN Bratislava.

[7] ŽSR SR 103-7 (S) Measurement and Evaluation of Track Geometry by Measuring Trolley KRAB (in Slovak), GR ZSR, 2008.

[8] IŽVOLT, L. et al.: Monitoring of Sections of Non-conventional Constructions of the Railway Superstructure and the Transition Areas - 5th and 6th Stage. ŽSR Modernization of Railway Track Nové Mesto nad Váhom - Púchov, km 100.500 to 159.100, part 24-32-01 Nové Mesto Trenčianske Bohuslavice (in Slovak), Žilina: KZSTH: SvF: University of Žilina, 03/2014.

[9] Continuously measuring trolley KRAB ${ }^{\mathrm{TM}}$-Light. Available on internet: http://kzv.cz/Czech/krab.php. 